\title{
INVENTORIES IN NATIONAL ECONOMIES
}

Egy adott makrogazdaság teljesítményét jellemzően annak bruttó hazai termékével (GDP) mérjük, azaz az adott országban, adott idő alatt megtermelt, végső felhasználásra szánt javak piaci áron vett összértékét számoljuk. A sztenderd kategorizálás szerint a megtermelt javak négyféleképp hasznosulhatnak: a háztartások és a nonprofit intézmények végső fogyasztásaként, az államháztartás végső fogyasztásaként, bruttó felhalmozásként, valamint nettó exportként. Azt nem merném kijelenteni, hogy a GDP ezen négy felhasználási módja közül a felhalmozás a legfontosabb kategória, ám az mindenképp elmondható, hogy a makroökonómiában több szempontból is kiemelt figyelem irányul rá, nem véletlen tehát, hogy közgazdászok garmadája tanulmányozza azt. A bruttó felhalmozást további két kategóriába szokás sorolni: állóeszköz-felhalmozás és készletváltozás. A könyv az utóbbival foglalkozik. Ha megvizsgáljuk hazánk, a KSH által publikált statisztikai adatait 1995 és 2017 között, akkor azt láthatjuk, hogy a készletváltozás az összes bruttó felhalmozásnak átlagosan 5\%-át adja, a teljes GDP-n belüli aránya pedig alig haladja meg átlagosan az 1\%-ot. És a számok hasonlóan alakulnak a fejlett világ más országaiban is. Érdemes egy ilyen, méretét tekintve teljesen lényegtelennek tủnő kategóriáról egy háromszáz oldalas könyvet írni?

A könyv 1. fejezete a készlet fogalmának definiálásával indít, és rögtön ezután választ is kapunk az imént felmerült égető kérdésre (vélhetően a szerzők is érezték annak relevanciáját): igen, érdemes. A szerzők roppant ötletesen, a szubmikro szinttől indulva és a makroszintig eljutva mutatják be a készletek szerepét, érvelve amellett, hogy valóban egy releváns jelenségről van szó. A könyv 2. fejezetében irodalmi áttekintést kapunk, mégpedig ugyanazon logikai elven, amelyet az előző fejezetben megismerhettünk: a mikroszinttől a makroszint felé haladva. Tárgyalásra kerül a vállalati szintü, a szektorszintủ és végül a makroszintủ készletezés elméleti és empirikus irodalma. A fókusz ugyanakkor a makroszinten van. A szerzők több szempont mentén mutatják be a kapcsolódó irodalmat: nem véletlenül, a leírások remek alapot adnak a későbbi empirikus elemzéshez, amely szintén a nemzetgazdasági szintre fókuszál, amelyről addigra már elhiszi az olvasó, hogy valóban megéri vele foglalkozni.

Az irodalmi áttekintés után a könyv következö, 3. fejezete a Módszertan címet viseli, ugyanakkor a használt módszertan valójában nem igazán kerül bemutatásra, pusztán egy felsorolás és a legfontosabb mozzanatok kiemelésének erejéig, bár talán nincs is többre szükség, hiszen többnyire roppant egyszerü eszközöket használnak a szerzők, a haladóbb statisztikai eszköztárat felvonultató fejezetek- 
nél pedig a függelékben részletesebb módszertani leírást is közölnek. A fejezet jóval nagyobb része szól a használt adatok bemutatásáról.

A könyv második fele, a 4., 5. és 6 . fejezetek pedig az empirikus elemzést tartalmazzák. A szerzők az elemzés során $32(20+6+6)$ országot vizsgálnak, alapvetően az 1970 és 2013 közötti időszak adatait alapul véve. Három országcsoport kerül górcső alá: (i) a hosszú idősorokkal (1970-2013) jellemezhető tradicionális piacgazdaságok: Amerikai Egyesült Államok, Ausztrália, Ausztria, Belgium, Dánia, Dél-Korea, Egyesült Királyság, Finnország, Franciaország, Hollandia, Izland, Izrael, Japán, Kanada, Németország, Norvégia, Olaszország, Spanyolország, Svédország és Új-Zéland, (ii) a csupán rövidebb idősorral jellemezhető piacgazdaságok: Chile, Görögország, Írország, Portugália, Svájc és Törökország, valamint (iii) a posztszocialista országok: Csehország, Észtország, Lengyelország, Magyarország, Szlovákia és Szlovénia. A 4. fejezet a három említett országcsoportra mutatja be a készletalakulást alapvetően két dimenzióban gondolkodva: idő és aggregáltsági szint szerint. Így tehát megismerhetjük a készletalakulások hosszú távú trendjeit, azok irányultságát és volatilitását, valamint rövid távú viselkedését, azaz a készletciklusokat (némiképp furcsán hat ugyanakkor, hogy az utóbbit igen röviden tárgyalják, holott a készletalakulás makroökonómiai szempontból jóval relevánsabb kérdés rövid távon). A készletek mozgását a szerzők különböző makroökonómiai változókkal is összekötik, és a kapott korrelációs együtthatók alapján az országok klaszterelemzését is elvégzik. Ennek eredményeképp kialakulnak olyan országcsoportok, amelyek hasonló profillal rendelkeznek. Az említett másik elemzési dimenzió pedig az aggregáltsági szint: a szerzők a makroszintű készletalakulások gazdasági ágazatokkal való együttmozgását is elemzik, az adatok elérhetősége miatt azonban ezt már csupán a húsz, hosszú múltú piacgazdaság esetén teszik. Az 5. fejezetben a használt makroökonómiai változók rövid elemzését olvashatjuk. A könyvnek nem célja ezen változók alapos elemzése, a prezentált tömör és leíró jellegủ analízis inkább arra alkalmas, hogy a készletvizsgálatnál kapott eredményeket az olvasó el tudja helyezni, és könnyebben értelmezze azokat. A 6. fejezet pedig országszintű elemzéseket tartalmaz: a szerzők leírják az egyes országokat jellemző folyamatokat, valamint bizonyos országspecifikus jelenségekre is kitérnek.

A teljes elemzésre igaz, hogy a szerzők jelentős vizualizációs erőket mozgatnak meg az információátadás érdekében. Sajnos a könyvben bemutatott ábrák nagyjából annyira rendezettek és egységesek, mint a napóleoni sereg Waterloo után, de még így is sokat segítenek a rengeteg információ feldolgozásában, az ábrák által közvetített információk sokkal könnyebben befogadhatóak, mint a végtelen mennyiségü számadat.

Összességében tehát elmondható, hogy a könyv a készletalakulások roppant alapos leíró elemzését mutatja be. Látszik továbbá az is, hogy javarészt rutinos, hosszú pályát maguk mögött tudó egyetemi oktatók a szerzők, hiszen az infor- 
máció közlése végig nagyon didaktikus, a folyamatosan feltünő bevezetések és összefoglalások nagyon jól strukturálják a mondanivalót. Érdemes tehát elolvasni a könyvet? Ha szeretnénk egy átfogó és alapos elemzést olvasni a nemzetgazdaságok készletberuházásainak hosszú távú alakulásáról, folyamatairól, törvényszerüségeiről, akkor igen, mindenképp.

(Attila Chikán - Erzsébet Kovács - Zsolt Mátyusz - Magdolna Sass - Péter Vakhal: Inventories in National Economies - A Cross-Country Analysis of Macroeconomic Data. London: Springer, 2018, 328 o.)

Tőkés László

egyetemi tanársegéd Budapesti Corvinus Egyetem Makroökonómia Tanszék 